This is an open access article under the terms of the CC-BY 3.0 License.

Peer review method: Double-Blind

Date of acceptance: November 16, 2020

Date of publication: January 08,2021

Original scientific article

DOI: https://www.doi.org/10.47305/JLIA2163052s

\title{
DIVERGENCES FROM THE SEPARATION OF POWERS IN TIMES OF EMERGENCY WITH SPECIAL EMPHASIS TO THE REPUBLIC OF NORTH MACEDONIA
}

\author{
Vesna Stefanovska \\ Institute for Human Rights - Skopje, Republic of North Macedonia \\ ORCID iD: https://orcid.org/0000-0003-3236-5189 \\ vesna.stefanovska87@gmail.com
}

\begin{abstract}
The worldwide pandemic caused by the coronavirus has disturbed the pure conception of the separation of powers. States forced by the newly established situation, declared a state of emergency, thus the Republic of North Macedonia was not an exception. This paper will focus on the divergences from the separation of powers in the countries from the Western Balkans and across Europe whose departure in the well-established system of checks and balances intrigued the media. The case of North Macedonia was maybe the most interesting because in time of declaring the state of emergency by the President of the Republic, the legislative branch of power - the Assembly was dissolute which meant that the already difficult situation became more complicated to establish a balance between the branches of power to function in protecting the general health of the citizens and the fundamental human rights and freedoms.
\end{abstract}

Keywords: Separation of Powers; Pandemic; COVID-19; State of Emergency; Human Rights 


\section{INTRODUCTION}

In times of emergency when the life of the nation is threatened by the coronavirus, several segments are in a position to be jeopardized such as the public health, functional democracy, rule of law, the protection of fundamental human rights and freedoms, and the possibility of introducing regimes which not only disturb the balance between the branches of power but also can cause irreversible damages. This requires posing a borderline between the needs of the citizens and the presumption of preventing possible autocracy.

In the past years, states of emergency have been declared in several states across Europe such as France (2015), Belgium (2015), and Turkey (2016) due to different reasons which involve terrorist violence, coup attempts, and domestic disturbances. The pandemic caused by the COVID-19 not only changed the perception of everyday life but also made divergences in the separation of powers, limitation to fundamental human rights and freedoms, and serious health crisis which affected all segments of power. In the Republic of North Macedonia, the state of emergency was declared in March 2020 in the specific circumstance of a dissolved Assembly which could not act as a controller of the Government's performance in extraordinary conditions.

This paper will focus on the legal aspects of declared states of emergency, divergences from the well-established separation of powers, and gaps in the Constitution that may cause different interpretations of constitutional provisions. The subject of analysis will be the relations between the Government as the organ that can deliver decrees with a force of law and the 'substitutive' control mechanisms located in the President of the Republic and the Constitutional Court. Finally, the paper will argue the lessons learned from this pandemic and the need for intervention in the Constitution, adoption of a Law on the state of emergency, and the dilemma of what will happen if the decisions for declaring a state of emergency are not approved by the Assembly.

\section{THE EVOLUTION OF THE SEPARATION OF POWERS: FROM MONTESQUIEU TILL CONTEMPORARY TIMES}

Democracy has many shapes, but it is usually predicated upon an effective separation of powers between the legislature, executive, and judiciary. In such terms, democracy may be related to functional institutions and the rule of law as we are familiar with nowadays. The doctrine of separation of powers between independent and co-equal branches of government is derived from the work of the French politician and social philosopher Baron de Montesquieu. In his 'The Spirit of the Laws' (Evans and Davies 1748) he defined the principle of separation of powers. Therefore, Montesquieu stated that: "in every government, there are three sorts of power: the legislative, the 
executive in respect to things dependent on the law of nations and the executive regarding matters that depend on the civil law (...)" (Evans and Davies 1748, 198-199). The separation of powers refers to the division of government responsibilities into distinct branches. Montesquieu asserted that these three branches of powers must be divided into a person and in function and they must act independently (Omejec 2015). Thus, this tripartite system is based on mutual checks and balances. The phrase check and balance implies that there are competing sovereigns. Checks refer to the ability, right, and responsibility of each power to monitor the activities of the other, while 'balance' refers to the ability of each entity to use its authority to limit the power of the other (Tasneem 2012). Broadly speaking, the legislature writes and adopts the laws, the executive enforces the laws, and finally, the judiciary delivers judgments about what laws mean and determines any violations. Precisely, this system of checks and balances ensures that the power is not vested in any single individual or organ and secures balance between institutions and at the same time enhances efficiency in exercising laws and protection of fundamental rights. In this way, there is clear supervision between the branches, because in practice abuses and excess mostly lie with the executive and its influence on the other two branches of powers.

In contemporary democracies, the doctrine of separation of powers is enshrined in the constitutions and even in some of them listed as the fundamental values of the state. That is the example with the countries from the Western Balkan, while in the rest of Europe; it depends on the constitutional order of the state and system of governance (parliamentary, presidential state, etc.).

In the Constitution of the Republic of North Macedonia, the separation of powers is considered as one among the fundamental values, where it is prescribed that the separation of state powers into legislative, executive, and judiciary is considered as a fundamental value of the constitutional order and the rights and obligations between these branches of power are listed in details in the Constitution (Constitution of North Macedonia 1991).

\section{DIVISION OF POWERS AMONG EUROPE IN TIMES OF EMERGENCY}

The dramatic spread of the COVID-19 which was declared a pandemic by the World Health Organization on 30 January 2020 has confronted states with unprecedented institutional challenges and has obliged institutions and governments to adopt strict measures effective citizens' rights. These reactions were followed with serious divergences in the separation of powers to declare a state of emergency and to uphold necessary measures. While some Member States' constitutions include a mechanism allowing for recourse to a state of emergency or the entrustment of special powers to specific institutions, other Member States' legal order does not, either for historic or owing to institutional tradition. Crucial aspects of the exercise of public 
powers under a pandemic threat include not only the extent of the measures adopted but also their legitimacy, raising the question of their duration and the degree of parliamentary oversight (EP Briefing 2020). The regulation of the state of emergency depends greatly on the constitutional order of the state concerned. Some states of emergency are regulated in constitutions and/or in-laws of special nature with different names such as 'state of war', 'state of siege' or 'martial law' and mostly, they address extraordinary situations which arise upon specific conditions, such as war, health or epidemic emergencies. Due to coronavirus, a state of emergency was declared in 10 Member States of EU (Italy, Lithuania, the Czech Republic, Latvia, Bulgaria, Slovakia, Romania, Finland, Luxembourg, and Portugal). Six more Member States have declared similar regimes: Hungary declared a 'state of danger', Croatia issued a 'declaration of epidemic disease', Estonia declared an 'emergency', Spain a 'state of alarm', France a 'state of sanitary emergency', Poland a 'state of epidemic threat' (EP and LIBE Committee 2020). The other Member States used normal legislation or decrees to adopt appropriate restrictive measures.

If we observe the regulation of the state of emergency in some of the EU Member States, we can notice the different application of norms in distinct terms and laws. For example, the Belgian Constitution has no specific provisions dedicated to the state of emergency in stricto sensu. On the contrary, the Constitution, in Article 187 clearly states that the Constitution cannot be suspended, but there is a mechanism named 'special powers' which may be triggered by the Belgian Parliament to delegate legislative powers to the government (The Constitution of Belgium 1831). The French Constitution does not recognize the term 'state of emergency' and instead refers to the state of siege proclaimed by the Council of Ministers and a lasting maximum of 12 days unless prolonged by the Parliament with a strict specification to the territory to which it applies (The Constitution of France, Article 36). In Germany, the provisions about the state of emergency were added in the Basic Law in 1968 to allow the Federal Government to react in crises. Ever since, the Basic Law has distinguished between internal and external states of emergency, The first covers situations when the country finds itself under military attack or facing an imminent threat, while the latter covers two specific regimes, the 'state of tension' governed by Basic Law and the 'state of defense' set out in Basic Law (Basic Law of Germany 1949). The Italian Constitution does not set out rules for a state of emergency or the transfer of power between the three branches, however, the Constitution provides for the declaration of a state of war with attribution of the necessary powers to the government (Constitution of Italy 1948).

Activated emergency powers are triggering implications in the well-established separation of powers by concentrating the whole power in the executive (government), while the legislature and judiciary are suspended by their powers. This situation also causes limitations in the fundamental human rights and freedoms by posing restrictions in the right of free movement, exercising the right to asylum, freedom of assembly, 
freedom of expression, etc. The main fears when declaring a state of emergency lie in the fact that the given authorities can be abused concentrated in one branch of power and used to create regimes opposite the need to deal with the pandemic and health crisis. Hungary and Poland are the best examples of these attempts to use the health crisis to establish autocracy.

In Hungary, the Government delivered a decision to prolong the state of emergency indefinitely, to authorize the Government to rule by decree without time limit and to weaken the emergency oversight of the Parliament. The emergency law is known as the 'authorization act' passed by the Hungarian Parliament on 30 March 2020 without specifying the term limit. The state of emergency was used to limit certain human rights, such as spreading fake news was considered as a jailable offense and the local government revenues have been redirected to the central government (Bozoki 2020). While, the Polish Government changed the electoral code against the judgment of the Constitutional tribunal and provisions laid by law and hold Presidential elections in the middle of a pandemic, which endangered the lives of Polish citizens and undermined the concept of equal, free, direct, and secret elections as enshrined in the Polish Constitution (EP Resolution 2020/2616(RSP)).

\section{STATE OF EMERGENCY VIS-À-VIS SEPARATION OF POWERS IN THE REPUBLIC OF NORTH MACEDONIA}

The Republic of North Macedonia has imposed one of the strictest mobility restrictions on citizens in Europe to prevent the Italian scenario where thousands of people died as a result of coronavirus and the cities and whole regions were put in lockdown. The state of emergency in the Republic of North Macedonia is regulated in the Constitution i.e. in the Seventh chapter. Article 125 regulates that:

A state of emergency exists when major natural disasters or epidemics take place. A state of emergency on the territory of the Republic or part thereof is determined by the Assembly upon a proposal by the President of the Republic, the Government, or by at least 30 representatives. The decision to establish the existence of a state of emergency is made by a two-thirds majority vote of the total number of representatives and can remain in force for a maximum of 30 days (Constitution 1991).

Hence, in absence of a separate law on the state of emergency, the Constitution in Article 125 determines the conditions which need to be fulfilled to establish a state of emergency and the duration of it. Following these provisions, on 18 March 2020, the Government asked the Assembly to declare a state of emergency. However, the Assembly was dissolved on 16 February 2020 due to the scheduled pre-term elections which were supposed to be held on 12 April 2020. 
Due to this unexpected circumstance, paragraph 3 from Article 125 was activated, where it prescribes that "if Assembly cannot meet the decision to establish the existence of a state of emergency is made by the President of the Republic who submits it to the Assembly for confirmation as soon as possible".

Establishing the state of emergency by the President of the Republic meant that the whole power will be concentrated in one branch - the executive in a situation of a dissolved Assembly that cannot exercise its control function over the Government's performance. Thus, Article 126 from the Constitution was triggered where the legislator prescribed that: "during a state of emergency, the Government following the Constitution and law, issues decrees with the force of law. The authorization of the Government to issue decrees with the force of law lasts until the termination of the state of emergency, on which the Assembly decides". In this specific circumstance when the Parliament is not in session, the only control mechanism that can prevent the Government in order not to cross its authorizations in delivering decrees with a force of law is the Constitutional Court.

In the most critical period when the country fought with the coronavirus, the President of the Republic issued three decisions for establishing a state of emergency. The first and second decisions were adopted to protect and deal with the consequences of the spreading of COVID-19, while the third referred to giving the possibility to the Government to adopt economic measures assisting those who suffered economically as a consequence of the epidemic.

The decisions for declaring a state of emergency were subjected to review by the Constitutional Court. The initiative for the first state of emergency was rejected because the declaration was not in force anymore (Decision U.No.41/2020). The second decision for declaration of a state of emergency was also subject to review by the Constitutional Court where the Court rejected and decided that the prolongation of a state of emergency for additional 30 days is constitutional. The Constitutional Court stated in particular that "if conditions for a state of emergency are still valid, which is a constitutional ground and a basic condition, a new decision for the state of emergency should be adopted" (Resolution U.no.55/20). All preconditions were fulfilled: there was a new evaluation of the current situation, where it was established that there is a need for declaring a new state of emergency for additional 30 days.

It is important to emphasize that the coronavirus did not cause disturbances only in the separation of powers and the way how the country was ruled in a time of emergency, but also has repercussions on the fundamental human rights and freedoms. In April 2020, North Macedonia made a derogation under Article 15 of the European Convention on Human Rights from Article 8 (the right to respect for private and family life), Article 11 (freedom to assembly and association), as well as from Article 2 of the Protocol No. 1 (the right to education) and Article 2 of the Protocol No. 4 (the freedom of movement). Note verbale informing the Council of Europe for derogations from the 
Convention's rights was submitted on 2 April 2020. Similarly, as declared states of emergency, limitations to human rights were posted before the Constitutional Court. In the first decision, the Court concluded that the Constitution allowed restricting certain human rights only in a limited number of cases determined by the Constitution which allowed limitations on the right to movement, right to strike, and right to peaceful assembly (Constitution 1991, Articles 21, 27 and 38). In Resolution 42/2020, the Constitutional Court emphasized that certain human rights including those that consider inviolable cannot be subjected to restrictions such as the right to life, prohibition to torture, determination of punishable offenses and sentences as well as to the freedom of personal conviction, conscience, thought and religious confession. However, the most affected right with the declaration of the state of emergency was the right of movement which was restricted both internally and cross-border. The most affected by the limitations in the freedom of movement were the minors under the age of 18 and the persons above the age of 67 which were left a couple of hours to move freely. This decision was challenged before the Constitutional Court, which issued a temporary measure suspending its implementation as potentially discriminatory based on age (Decision U.No.60/2020). Several decrees with a force of law delivered by the Government in times of emergency were questioned before the Constitutional Court:

- The Decree with a force of law for determining the limit of the salary of elected and appointed officials in the public sector for the time of emergency was nullified (Decision U.No.44/2020);

- The Decree with a force of law on limitation of payment of public sector employee's' benefits and compensation for the period of the emergency was nullified because the Constitutional Court determined that the limitation of the labor rights does not has a constitutional basis (Decision U.No.49/2020);

- The Decree with a force of law for public prosecutors' servants, investigators, and other employees in the Special Prosecution Office (SPO) was also nullified (Decision U.No.45/2020); and

- The Decree with the legal force for terms of judicial proceedings in a state of emergency and work of courts and public prosecutors were nullified (Decision U.No.56/2020).

Hence, extraordinary conditions caused by the coronavirus and the state of emergency have disturbed not only the well-established separation of powers but also affect the normal exercise of fundamental human rights and freedoms. The Macedonian case was maybe the most extraordinary due to the dissolved Assembly, technical Government established for organizing the parliamentary elections, and the states of emergency declared by the President of the Republic which activated the specific constitutional provisions giving the Government right to deliver decrees with a force of law. However, this right is not absolute, which points to the fact that the decrees with a 
force of the law should be subjected to strict criteria for their necessity and proportionality (Kambovski et. a/2020). This connotation implies that the parliamentary democracy should not be suspended in times of emergency, checks and balances must exist although their location now should be traced to the President of the Republic when declaring a state of emergency and the Constitutional Court when decides upon submitted initiatives about the constitutionality and legality of the decrees with a force of laws and their accordance with Constitution. This control is necessary to avoid the creation of regimes and delivering decisions that are not related to the state of emergency.

\section{CONCLUDING REMARKS: WHAT AFTER THE STATES OF EMERGENCY?}

The pandemic caused by the COVID-19 has shown the weaknesses of the Macedonian legal system in terms of existing legal gaps, firstly in the Constitution. As elaborated previously in this paper, there is no doubt that we need a Law on the state of emergency upon Article 124 and 125 from the Constitution, where all segments of the state of emergency will be covered especially putting the focus on the functioning of the Government in extraordinary conditions and defining the procedure for delivering decrees with a force of law, the control and the liability in case of abuses. Moreover, the decrees with a force of law must be delivered only for matters with fall under the terms of the state of emergency and dealing with the pandemic. This means that other issues that are not related to the pandemic cannot be considered as part of the state of emergency. This requires that the principle of proportionality must be taken into consideration. The measures undertaken in the state of emergency must be proportionate to the danger and the threat upon the nation concerned. One specific concern is the lack of determination of the duration of the decrees with a force of law delivered by the Government in a state of emergency. The question concerns if the legal force ends automatically with the repealing of the state of emergency or some legal conditions and relations can be continued after the state of emergency? What is intriguing about this situation is that even the Constitutional Court did not answer this question. This is just one example of what can be included in the Law on the state of emergency. The Assembly of the Republic of North Macedonia has been in session for more than three months after the parliamentary elections and still, the decisions for declaring a state of emergency have not been confirmed. It is not clear why we need the Assembly to confirm the decisions for states of emergency several months after their declaration. What will happen if the Assembly decides not to confirm these decisions and what political repercussions can we face? Restitutio in integrum cannot apply for these specific circumstances and it is more than evident that we need to specify certain provisions in the Constitution, moreover because this was the first time when the state of emergency has been declared from the country's independence. 


\section{REFERENCES}

1. Bozoki, András. 2020. Unlimited powers in the time of the pandemic. Green European Journal accessed 25 October 2020

https://www.greeneuropeanjournal.eu/unlimited-powers-in-the-time-of-thepandemic/

2. Evans, T and Davies, W. 1777, "The standard edition of The Complete Work of M. de Montesquieu translated from the French in Four Volumes", Volume the first (The Spirit of Laws).

3. European Parliament, 2020. "State of emergency in response to the coronavirus crisis: Situation in certain Member States", accessed 25 October 2020https://www.europarl.europa.eu/thinktank/en/document.html?reference=EP RS BRI(2020)649408

4. European Parliament and LIBE Committee, 2020. "The impact of Covid-19 Measures on Democracy, the Rule of Law and Fundamental Rights in the EU"https://www.europarl.europa.eu/RegData/etudes/BRIE/2020/651343/IPOL BRI (2020)651343 EN.pdf

5. European Parliament. 2020. "Resolution on EU coordinated action to combat the COVID-19 pandemic and its consequences" (2020/2616(RSP)

6. Omejec, Jasna. 2015. "Principle of the separation of powers and the constitutional justice system". Conference of constitutional control bodies of Central Asia "The Role of the Constitutional Court in Safeguarding the Supremacy of the Constitution" accessed 01 November 2020 https://bib.irb.hr/datoteka/785200.Omejec Separation of Powers and Constitutional Judiciary - Strasbourg 28.10.pdf

7. Tasneem, Sultana. 2012. "Montesquieu's Doctrine of Separation of powers: A Case study of Pakistan". Journal of European Studies Vol.28(2), pp.55-71

8. Kambovski, Vlado. Pavlovska-Daneva, Ana. Lažetiḱ, Gordana. Mujoska-Trpeska, Elena. Bitrakov, Konstantin.2020. "Pravni aspekti na vonrednata sostojba" https://www.researchgate.net/publication/344044925 PRAVNI ASPEKTI NA VON REDNATA SOSTOJBA

\section{Legal acts and decisions:}

1. Basic Law for the Federal Republic of Germany adopted on 8 May 1949,

2. Constitution of Belgium proclaimed on 7 February 1831 year,

3. Constitution of the French Republic proclaimed on 4 October 1958 year,

4. Constitution of the Italian Republic, Official Gazette Dec. 27, 1947, no. 298,

5. Constitution of the Republic of North Macedonia, Official Gazette of the Republic of North Macedonia No. 52/1991, 
6. The Decision by the Constitutional Court of RNM, U. No.41/2020 from 6 May 2020.

7. The Decision by the Constitutional Court of RNM, U. No.44/2020 from 28 April 2020.

8. The Decision by the Constitutional Court of RNM, U. No. 45/2020from 28 April 2020.

9. The Decision by the Constitutional Court of RNM, U. No .49/2020from 28 April 2020.

10. The Decision by the Constitutional Court of RNM, U. No. 56/2020 from 12 May 2020.

11. The Decision by the Constitutional Court of RNM, U. No. 60/2020 from 14 May 2020

12. Resolution by the Constitutional Court of RNM, U. No.55/2020 from 12 May 2020. 